\title{
USE OF LIBRARY AND INFORMATION SERVICES FOR LEGISLATIVE RESEARCH
}

\author{
JOEL-IKOKOH, Enatta Catherine \\ Documentalist \\ Policy Analysis and Research Project \\ National Assembly. \\ P.M.B. 123, Garki. Abuja \\ email: cathrine_ikoho@yahoo.com
}

\begin{abstract}
The paper looks at information as a critical element in life, society and as an inevitable aspect in the day to day management by the legislators. It outlines and explains legislative services, the roles of library and information services, research services in library and information setting, challenges of library and information services in a legislative library environment.
\end{abstract}

Keywords: Legislature, National Assembly, Library services, Legislative research, Information.

\section{Introduction}

Information has become a critical element in life and society. It is an important part of development. In a developing legislature like Nigeria, information in all aspects of life need to be collected to assist legislators in their day to day management process. The legislature needs as much information as it can get to aid its work. The legislators need up to date information on the activities of the state legislators to ensure consistency and synergy between both levels. Nisbert and Schucksmith (1986) asserted that "the most important learning is learning to learn. The most important knowledge is self knowledge".

Nigeria has three tier legislature; we have the National Assembly which is at the Federal government level, the State House of Assembly at the State level and the local council at the local government level. The constitution of the Federal Republic of Nigeria (1999) contains provision regulating its National Assembly. The legislative powers of the Nigeria federation are vested by the 
constitution in the National Assembly which is made up of the Senate and the House of Representatives. The material copy of the Senate and the House of Representatives competence is broadly defined as that of making laws for the peace and order and government of the federation or any part thereof, but restricted to matters specified in the Executive legislative list as set out in part of the second schedule to the constitution.(s4)(2).

\section{Legislative research services}

Legislative research services means the provision of value added research projects and services, as distinct from traditional library and information services offering access to sources (books, serials, document, database, CD ROMs etc), bibliographies, quick reference and assistance. A legislative research service prepares and provides information dossiers, in-depth subject studies, pro and contra arguments, briefing to parliamentarians; and other services or product of similar breath and scope; published or not.

The word research refers to the aggregation of knowledge beyond that found in traditional library and information services.

\section{Roles of library and information services}

The role of library and information services in legislative operations cannot be over emphasised. Within the office of Policy Analysis, library and information services provide reference and research services to committees, members, and staff of the General Assembly, and the legislative information to the public. The library offers core services for learning and research. It plays the role of support to the legislative learning through the provision and control of information in print and other media, through assistance with its retrieval and through provision of facilities for its use;

It gives the legislature an ability to gather information from primary and secondary sources of information to enhance their research work. It serves as access to scholarly literature and information held elsewhere. The library helps the legislature to be able to quote, paraphrase and summarise accurately and to also cite sources properly. 
The library serves as a tool of excellence and in the promotion of life long learning by the provision of learning environment which integrates reading places, information technology and materials for study and research. It serves as an official depository for the publication of the legislature. It has a collection of first sort in all media. The library serves as a store house of knowledge or a super high way. According to Banjo (1981), the library plays the role of contributing to the speedy development of community, implants ideas, opens up minds, fires imagination, releases the brake of ignorance and reinforces the dynamics of progress, inspires young men to see vision and when they grow old, it helps them to dream peaceful dreams.

\section{Research services in library and information setting}

Legislative research institutions face growing demands for their services on one hand, and must keep up with an avalanche in the field of information science on the other hand. The following are research services provided in a library and information setting to a legislative researcher.

Provision of parliamentary library with traditional service such as the organization of knowledge, collection and reference work. The organization of knowledge might differ from one parliamentary library or the other depending on the classification scheme in use by that particular library. The researcher must study the scheme in use to enable him or her use the facilities available effectively. There are different types of classification schemes in use ranging from home grown to those popularly in use by libraries such as the Dewey Decimal Classification Scheme known as the DDC; it uses numbers such as 000-900 in classifying the knowledge. There is also the Library of Congress Classification Scheme known as LC, the Universal Decimal Classification scheme known as UDC, and a host of others. The collections in legislative libraries are mainly in the social science that will enhance the knowledge of the legislators. Reference work ranges from offering a quick reference services such as answers to questions as date of an issue etc. 
Provision of a group of non -traditional services and databases such as legislative and legal databases as well as other databases. There are different types of databases on sale that can enhance research work such as EBSCO HOST, JSTOR HOST etc that contain both legal and other information that can enhance legislative research work.

Provision of an electronic or virtual library services. It enables the researcher to hook to other library via the internet. According to Michalowski (1997), in Great Britain it is expected that the use of modern technology will greatly increase in the new parliament, both for the research services and on the part of the new members and their staff.

Provision of a research department with researchers to prepare research papers on demand for Senators and Honourable members. The researchers themselves are the major users of the library's information resources and reference services. They make use of the materials and provide the information to the various committees to enhance their work.

\section{Legislative Library services}

The Legislative library services are services provided by a library attached to any legislative body. It provides direct library services to the state government, and provides archival and record management services, technical assistance, education, financial aid, and cooperative services. Within this framework the legislative library services provide priority information and research services to the members and staff of the legislature. Library and information services provide reference and research support to the general assembly and its staff as well as the legislative information to the public.

Current Awareness (C A) services and Selective Dissemination of Information (SDI):

This involves the provision of information on new arrival into the library and also the provision of information on specific areas of 
interest of the legislative staff. The provision of advice and guidance to users in regards to books that will enhance the legislators' productivity. Provision of interlibrary loan and interlibrary reference services: The library staff/librarian checks other library to meet the needs of the legislative staff. No library has all the pool of information. Provision of indexing and abstracting services to the users: This is done through a search of various documents usually in printed form and by providing specific and summary of such items to the user.

Legislative information is provided through phone, e- mail, or face to face contact through the distribution of various legislative documents. Staff also coordinate and conduct educational programmes for visitors to the General Assembly (from time to time visitors from other country are taken around) including students' public interest group, interest groups, legislators and officials from other countries.

The collection consists of volumes of materials concerning history of the country, enacted and failed legislation; code and regulation of country; codes of other states; information on public policy topics such as taxes, education, corrections, health, and the environment; and other reference information of interest to the researcher such as newspaper collection, photo albums, order papers etc.

Information request services

Remote access to electronic databases (including law and many other areas)

Access to periodicals and other time sensitive materials.

Assistance in finding and using the library materials (microform, slides, electronic databases, online catalogue etc);

Instruction in computer searching using online or electronic databases.

\section{Challenges of library and information services.}

There are several challenges faced in the legislative library. It is true that for the legislators to succeed in their day to day work, the governments have no other choice than to plan for the establishment of functional libraries in all the legislative setting in 
the country. Material for these libraries must include encyclopaedia, book on social sciences that will enhance legislative research work and productivity.

In order to give the best to the legislatures and the general Assembly Staff, government must recruit qualified librarian and also embark on training and retraining of those who are already in the service, but unqualified.

It is always argued that legislative materials are in short supply in Nigeria. Nigeria writers should write more on legislative matters; articles in journals and books while government and non governmental organizations can sponsor writers by providing research grants.

Some of the challenges faced by the legislative libraries are outlined below.

Acquisition of material: With the proliferation of information resources/materials, librarians and libraries are faced with the challenges of how to choose among the myriad of materials that are presented to them.

User Attitude: The attitude of library users also constitutes challenges to the effective running of the library. Collection development is not a one man show, it involves the librarian and the users; but most of the time the users fail to present their material even with the publisher catalogues presented to them for response.

Acquisition of foreign books: Most of the materials found in our libraries in Nigeria are foreign and thus poses the problem of payment and processing.

Unqualified personnel: Most government officials look at library and librarianship as insignificant and therefore think that any person can render the services therefore leading to the provision of ineffective services 
Funding: Libraries and librarians are faced with the challenge of fund allocation to cater for the need of the library. Most establishments feel other thing should be provided before library can be taken care of. Sometimes fund meant for the library are diverted to other things.

Preservation and storage of materials: The weather in Nigeria is very harsh to books and other resource material. Libraries have poor storage and preservation facilities which lead to quick deterioration of books and other library materials.

Mishandling and theft of library material is also another challenge faced by libraries. Nigerians lack reading culture; we read when we are pressed for examination or other information; and so it leads to poor handling of those books we lay our hands on and, sometimes, these material are stolen from the library.

Library sensitization: There is need for proper education and sensitization of users on the use of the library which is lacking in most libraries.

\section{Conclusion}

The use of library and information services for legislative research can never be over emphasised. Library and information services are essential in legislative research in order to enhance the effective productivity of the legislature and therefore needs to be encouraged in all General Assembly. Finally, the services rendered by any library and information centre will be incomplete if solutions are not proffered to the challenges faced by the library.

\section{References:}

Dulce Maria Liahut Baldomar : "The role of the research services in modernization of Mexican Congress" Annual Conference 66 $6^{\text {th }}$ IFLA Council and General Conference of Jerusalem, Israel, 1318 August.

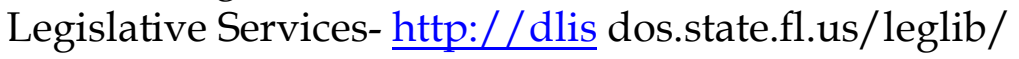

Michalowski Jacek (1997) Section on library and research services to for parliament. $63^{\text {rd }}$ IFLA general conference in Copenhagen, Denmark. 
Nisbet ,J and Schucksmith (1986) Learning strategies. London: Rutledge and Kegan Paul.

Policy Analysis and Research project National Assembly: (2007) Nigeria State assemblies: a study of legislative activities 1999 2005. 